\title{
Removal of Cobalt ions from Wastewater by Batch and flowing Forward Osmosis Processes
}

\author{
Tamara Kawther Hussein ${ }^{1}$ \\ 1 Department of Environmental Engineering, College of Engineering, Mustansiriyah University, Baghdad, Iraq \\ e-mail: tamarahussein@uomustansiriyah.edu.iq
}

\begin{abstract}
This study was focused on forward osmosis batch and forward osmosis flowing processes to remove heavy metal $\left(\mathrm{Co}^{+2}\right.$ ions) from wastewater. Cellulose triacetate (CTA) membrane was used as flat sheet for forward osmosis process. Potassium chloride $\mathrm{KCl}$ with different concentrations was used as draw solutions. The experimental work was divided into two parts. Forward osmosis flowing process as first part, was discussed under different operating parameters studied, such as the concentration of draw solutions 10-20 g/l, concentration of feed solutions $15-150 \mathrm{mg} / \mathrm{l}$, temperature of feed and draw solutions $20-50{ }^{\circ} \mathrm{C}, \mathrm{pH}$ of feed solution from 2 to 10 , feed and draw flow rate were maintained at $50 \mathrm{l} / \mathrm{h}$, and pressure was maintained at 0.25 bar gauge. Forward osmosis batch process as second part, was discussed under different operating parameters, such as the concentration of draw solutions 10-120 g/l, concentration of feed solutions $15-150 \mathrm{mg} / \mathrm{l}$, temperature of feed and draw solutions $20-50{ }^{\circ} \mathrm{C}$, and $\mathrm{pH}$ of feed solution from 2 to 10 . The results showed that the water flux increased along with the draw solution concentration, and temperature of feed and draw solutions and decreased with the increasing operating time of experiment, concentration and $\mathrm{pH}$ of feed solution. The value of rejection efficiency after $4 \mathrm{hrs}$ reached $81.19 \%$ for the FO flowing process and $73.19 \%$ for the FO batch process.
\end{abstract}

Keywords: heavy metal, wastewater, potassium chloride, forward osmosis, membrane separation.

\section{INTRODUCTION}

At present, water pollution is an important problem in the world. Heavy metals are discharged into the environment cause serious pollution problem for soil and water so it must be removed before water reuse or discharge to the environment [Kamar et al., 2017]. Large amounts of heavy metals in the environment may cause acute or chronic toxicity but small amounts of heavy metals are necessary for the human health [Abbas et al. 2014; Abdel-Raouf and AbdulRaheim, 2017]. Various industries release heavy metals, including pulp, paper mills, fertilizers, steel works and inorganic chemicals, etc. [Gupta et al., 2017]. Cobalt, naturally found in rocks and soils, is one of the heavy metal ions that affect the environment. The important sources of cobalt are manufacture of alloys, paint driers, permanent magnets and in industrial catalysts. Cobalt is one of toxic metal ions that cause allergic dermatitis, rhinitis and asthma [Sharma et al., 2015]. The most urgent problems being faced the worldwide is the removal of heavy metal contaminants from wastewater. Different techniques for the treatment of metal ions from effluent wastewater include chemical precipitation, coagulation-flocculation, adsorption, flotation, and ion exchange. The disadvantages of these techniques are incomplete removal of heavy metals, high-energy requirements and production of toxic sludge [Masoudzadeh et al., 2018].

Nowadays, the forward osmosis (FO) process is considered as an efficient technology for the membrane separation process. FO is process in which water transport across a semi-permeable membrane based on the natural osmotic process using a concentration gradient generated by low solute concentration of feed solution (FS) (low osmotic pressure) and high solute concentration of draw solution (DS) (high osmotic pressure) [Hsiang, 2011]. The osmotic pressure $(\pi)$ was 
calculated according to the Van't Hoff equation [Tang et al., 2011]:

$$
\pi=\phi i R_{g} T C
$$

where: $\pi$-osmotic pressure (bar),

$\Phi$ - osmotic coefficient,

$i$ - number of dissociated ions per molecule (van't Hoff factor),

$R_{g}$ - universal gas constant (liter bar/g. K),

$T^{g}$ - temperature $(\mathrm{K})$,

$C$ - concentration of solute $(\mathrm{g} / \mathrm{l})$.

FO does not require high pressure as in the case of the RO process, so it considered as a novel process especially for desalination [Ali et al., 2016]. The main advantages for FO treatment are low membrane fouling, low pressure application, and low cost. The draw solution was selected based on its high osmotic pressure, non-toxic, low cost, chemically inert character to the membrane, and the possibility of easy separation from pure product [Qasim, 2013].

The present work includes a study on the efficiency of FO flowing and FO batch processes as an application for the removal of $\mathrm{Co}^{+2}$ ions from wastewater. $\mathrm{KCl}$ was used as draw solution to recover water across cellulose triacetate (CTA) as a semi-permeable membrane, and also to study the effect of different parameters such as draw solution concentration, feed solution concentration, $\mathrm{pH}$ of feed solution, operating time of experiment and temperature of feed and draw solutions on water flux.

\section{MATERIALS AND METHODS}

\section{Preparation of feed solutions}

Different concentration samples of cobalt solution $(15,60,80$, and 150$) \mathrm{mg} / \mathrm{l}$ were prepared by dissolving the required amount of cobalt nitrate hexahydrate $\mathrm{Co}\left(\mathrm{NO}_{3}\right)_{2} \cdot 6 \mathrm{H}_{2} \mathrm{O}(\mathrm{Mwt}=291.03 \mathrm{~g} / \mathrm{ml})$ in deionized water (DI), of 3-8 $\mu \mathrm{S} / \mathrm{cm}$ conductivity. The solution $\mathrm{pH}$ was adjusted (2-10) using a pH meter (HANNA instruments, Model H198107, USA) by adding $0.1 \mathrm{M} \mathrm{HCL}$ or $0.1 \mathrm{M} \mathrm{NaOH}$ as required, and stirrer (MSH-300N, BOECO, Germany) was used to mix solution at an agitation speed of $500 \mathrm{rpm}$ for $20 \mathrm{~min}$. The feed solution total volume was 5 liters. The percentage removal of $\mathrm{Co}^{+2}$ ions $(R \%)$ in solution was calculated using Equation 2

$$
R(\%)=\frac{\left(C_{o}-C_{e}\right)}{C_{e}} \times 100
$$

where: $C_{\mathrm{o}}$ and $C_{\mathrm{e}}$ are initial and final concentrations of $\mathrm{Co}^{+2}$ ions at equilibrium in the water $(\mathrm{mg} / \mathrm{l})$, respectively.

\section{Preparation of draw solution}

A potassium chloride $\mathrm{KCl}(\mathrm{Mwt}=74.55 \mathrm{~g} / \mathrm{ml})$ solution used as draw solution was supplied from scientific equipment offices in Bab Al-Moatham markets, Baghdad, Iraq as powder. Deionized water of 3-8 $\mu \mathrm{s} / \mathrm{cm}$ conductivity, was used for preparing $\mathrm{KCl}$ solution with different concentration of $10,20,50,80$, and $120 \mathrm{~g} / 1$, and then $\mathrm{KCl}$ solution was mixed by using a stirrer at an agitation speed of $500 \mathrm{rpm}$ for $20 \mathrm{~min}$.

\section{Membrane}

An asymmetric FO membrane (cellulose triacetate (CTA)) acquired from Hydration Technology Innovations (X-Pack ${ }^{\mathrm{TM}}$ supplied by Hydration Technology Inc., Albany, OR) was used for $\mathrm{FO}$ flowing system and FO batch system.

\section{Experimental procedure}

\section{FO batch system procedure}

Figure 1 shows the forward osmosis batch system. The effective membrane area for batch system was $400 \mathrm{~cm}^{2}$. The volume of both draw solution (DS) and feed solution (FS) were 500 $\mathrm{ml}$, the cobalt feed solution was placed into the outer chamber of the bag while the draw solution $(\mathrm{KCl})$ was placed into the inner chamber of the bag. Subsequently, the batch system was placed in a constant-temperature water bath range from 0 to $80^{\circ} \mathrm{C}$ (VWR Scientific, IL) to maintain the desired temperature during the FO tests. Through osmosis, water transports from the feed solution (cobalt) across membrane to the draw solution (KCl). The experiment lasted for 4 hours. Every 0.5 hour, the volumes of feed solution and draw solution were measured by discharging both solutions in graduated cylinders, then the water flux through membrane was calculated by dividing the permeate volume by effective membrane area and time. The concentration of $\mathrm{Co}^{+2}$ ions permeate through CTA membrane was measured by Atomic Absorption Spectrometry (AAS) (AA-7000 Shimadzu, Japan). After recording the results and 


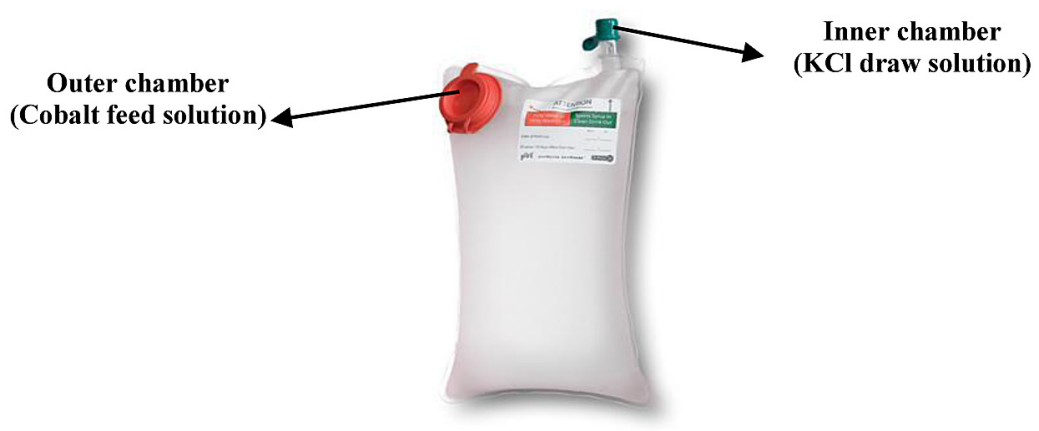

Figure 1. Batch system (Hydration Bag)

at the end of the experiment, the feed and draw solutions that remained in the bag were drained and the whole bag was washed with distilled water.

\section{FO flow system procedure}

The experiments were conducted in designed a laboratory-scale FO system consisting of two cylinders with a capacity of 7 liters where the feed and draw solution were placed, $\mathrm{KCl}$ draw solution and cobalt feed solution were pumped by two high pressure pumps (positive displacement, diaphragm pump) with inlet pressure 29 psi from vessels to direct osmosis element. In order to measure the volumetric flow rate of feed and draw solutions, two calibrated flow meters were used, each with the range $(10-60 \mathrm{l} / \mathrm{h})$. A pressure gauge range of $(0-2.5$ bar $)$ was used to indicate the pressure of feed solution. The temperatures of both solutions were controlled by two submersible electrical coils (220 Volt, 1000 Watt) and thermostat with the range from 0 to $80^{\circ} \mathrm{C}$. The forward osmosis cell consisted of two semi-cells which were made of teflon and two channels on both side of membrane with dimensions of $17.8 \mathrm{~cm}$ length, $11.7 \mathrm{~cm}$ width and $6 \mathrm{~cm}$ depth; the membrane provided an effective area of $208.26 \mathrm{~cm}^{2}$. Forward osmosis membrane orientated with the draw solution was suited at support layer and the feed solution was placed at active layer. The feed and draw solutions flowed tangentially to the membrane with co-current flow configuration to reduce strain on both sides of membrane and provide constant $\Delta \pi$ along the CTA membrane. The effluent streams of feed and draw solutions were recycled back to the main vessels. The pressure of 0.25 bar gauge was applied across the membrane sheets in the feed side for all experiments. The operating time of experiment was 4 hours. Increasing draw solution (DS) volume was measured every 0.5 hour and compared with the reduction in the feed solution (FS) volume. The water transported through the membrane was divided by the effective area of CTA membrane and the time to measure the water flux. The cleaning process was carried out by adding $10 \mathrm{~g} / 1$ of citric acid to the distilled water in the feed and draw vessels as well as circulating the solutions through two sides of FO cell, followed by flushing with deionized water. The scheme of forward osmosis set-up is shown in Figure 2.

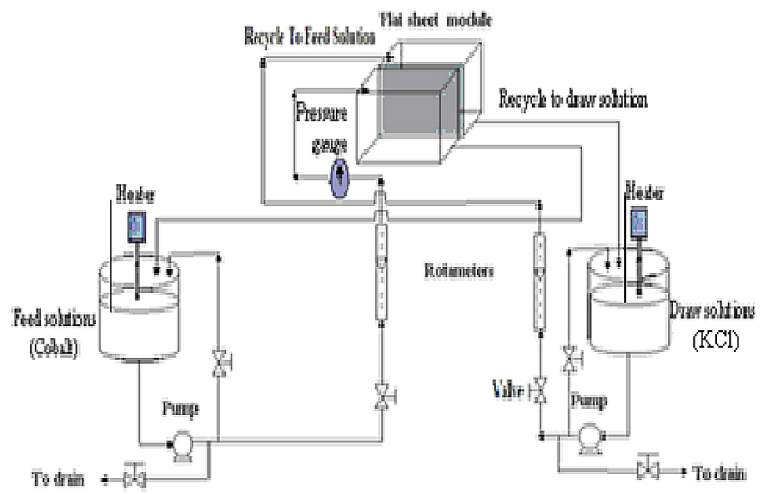

Figure 2. The schematic diagram of the laboratory scale forward osmosis membrane apparatus.

\section{RESULTS AND DISCUSSION}

\section{Effect of operating time on water flux}

Figure 3 illustrates the effect of time on water flux of feed solution $\left(\mathrm{Co}^{+2}\right.$ ions $)$ for $\mathrm{FO}$ flowing and FO batch processes. During the first hour of experiment, the water flux decline reached $37.96 \mathrm{1} / \mathrm{m}^{2} . \mathrm{h}$ for the $\mathrm{FO}$ flowing process and $28.44 \mathrm{l} / \mathrm{m}^{2} . \mathrm{h}$ for the FO batch process, and then after $2.5 \mathrm{hr}$ it reached steady state due to phenomenon of concentration polarization on the membrane, which led to a decrease in the osmotic driving pressure with time, which conforms to [Nematzadeh et al., 2015]. 


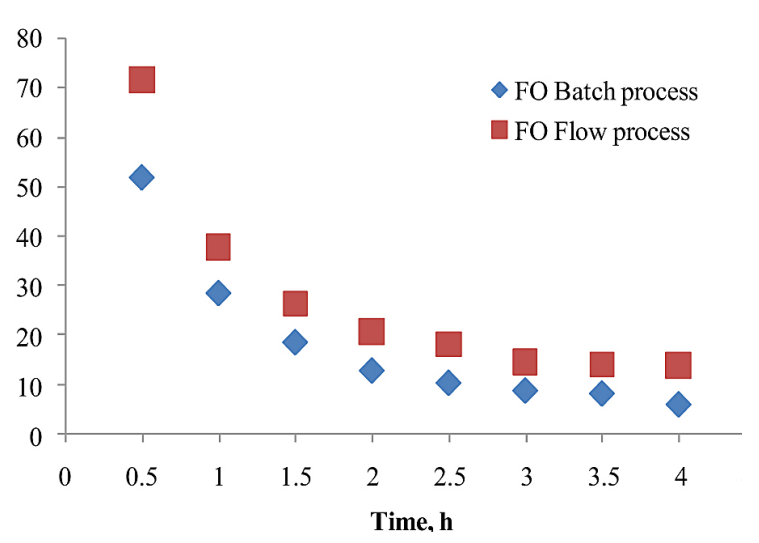

Figure 3. Water flux with time for FO flowing and $\mathrm{FO}$ batch processes $(\mathrm{KCl}$ concentration $=20 \mathrm{~g} / \mathrm{l}$, $\mathrm{Co}^{+2}$ ions concentration $=60 \mathrm{mg} / 1$, temperature of feed and draw solutions $=30^{\circ} \mathrm{C}, \mathrm{pH}$ of feed $=5$ ).

For FO flowing system (flow rate of feed and draw solutions $=50 \mathrm{l} / \mathrm{hr}$, and pressure $=0.25 \mathrm{bar}$ ).

\section{Effect of draw solution concentration}

Figure 4 illustrates the effect of draw solution concentration on water flux for the FO flowing and the FO batch processes. When the concentration of draw solution increased, water flux increased as well, reaching $25.68 \mathrm{1} / \mathrm{m}^{2}$.h for FO flowing process after $4 \mathrm{hrs}$. For the FO batch process at draw solution concentration $120 \mathrm{~g} / \mathrm{l}$, it reached $15.74 \mathrm{1} / \mathrm{m}^{2}$.h due to an increase in driving force. This behavior is in agreement with [Changwoo et al., 2012].

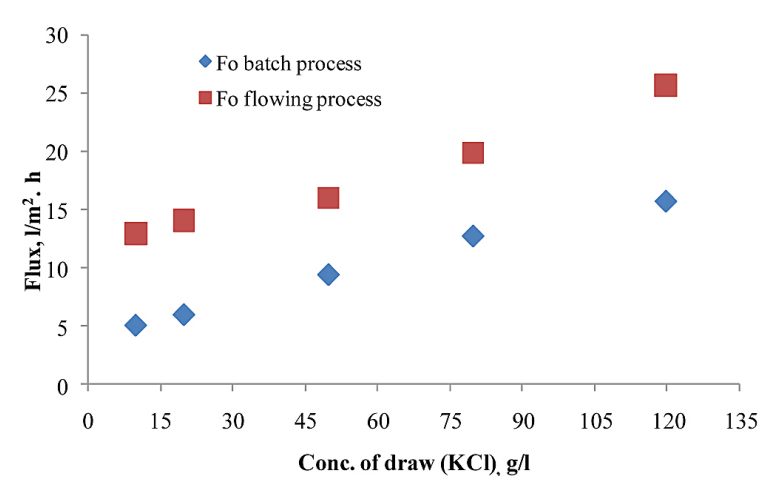

Figure 4. Water flux with $\mathrm{KCl}$ concentration for the $\mathrm{FO}$ flowing and the $\mathrm{FO}$ batch processes $\left(\mathrm{Co}^{+2}\right.$ ions concentration $=60 \mathrm{mg} / \mathrm{l}$, temperature of feed and draw solutions $=30^{\circ} \mathrm{C}$, $\mathrm{pH}$ of feed $=5$, time $=4 \mathrm{hrs}$ ). For the FO flowing system (flow rate of feed and draw solutions $=501 / \mathrm{hr}$, and pressure $=0.25 \mathrm{bar}$ ).

\section{Effect of feed solution concentration}

Figure 5 illustrates the effect of different feed solution concentration $\left(\mathrm{Co}^{+2}\right.$ ions) on water flux for the FO flowing and the FO batch processes. From this figure it can be seen that when the initial feed solution concentration increased, the water flux decreased reachinf $9.99 \mathrm{l} / \mathrm{m}^{2}$.h for the FO flowing process and $4.19 \mathrm{l} / \mathrm{m}^{2} . h$ for the FO batch process at concentration $150 \mathrm{mg} / \mathrm{l}$ of feed solution after $4 \mathrm{hrs}$. A decrease in the water flux was attributed to the increasing feed solution concentration which raised the osmotic pressure of the feed solution and reduced of driving force $(\Delta \pi)$. These conclusions correspond with the investigation of [Patil et al., 2016].

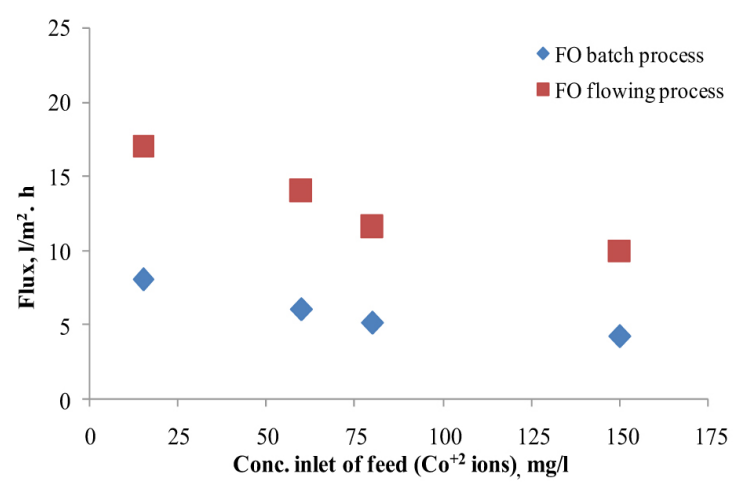

Figure 5. Water flux with $\mathrm{Co}^{+2}$ ions inlet concentration for the FO flowing and the FO batch processes $(\mathrm{KCl}$ concentration $=20 \mathrm{~g} / 1$, temperature of feed and draw solutions $=30^{\circ} \mathrm{C}, \mathrm{pH}$ of feed $=5$, time $=4 \mathrm{hrs}$ ). For the FO flowing system (flow rate of feed and draw solutions $=50 \mathrm{l} / \mathrm{hr}$, and pressure $=0.25 \mathrm{bar}$ ) .

\section{Effect of temperature}

Figure 6 shows the effect of both feed and draw solutions temperature on the water flux for both processes. When the temperature of feed and draw solutions increased from $\left(20-50^{\circ} \mathrm{C}\right)$,

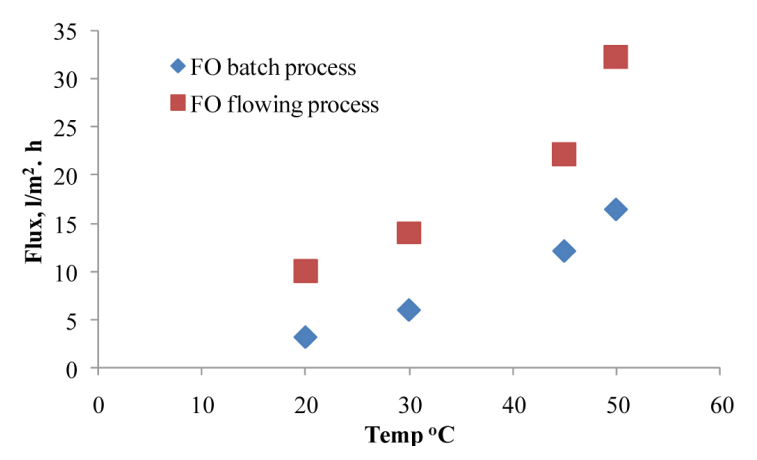

Figure 6. Water flux with different temperature of both feed \& draw solution for FO flowing and FO batch processes $\left(\mathrm{Co}^{+2}\right.$ ions concentration $=60 \mathrm{mg} / \mathrm{l}$, $\mathrm{KCl}$ concentration $=20 \mathrm{~g} / 1, \mathrm{pH}$ of feed $=5$, time $=$ $4 \mathrm{hrs}$ ). For the FO flowing system (flow rate of feed and draw solutions $=50 \mathrm{l} / \mathrm{hr}$, and pressure $=0.25 \mathrm{bar}$ ). 
the water flux increased linearly due to reduced viscosity of feed and draw solutions which led to an increase in the permeation of water through CTA membrane which after reached $32.34 \mathrm{l} / \mathrm{m}^{2} . \mathrm{h}$ for the FO flowing process and $16.431 / \mathrm{m}^{2} . \mathrm{h}$ for the $\mathrm{FO}$ batch process at temperature $50^{\circ} \mathrm{C}$ for both feed and draw solutions, after 4 hours of the experiment. This result corresponds with previous studies [Cui et al., 2014].

\section{Effect of cobalt feed solution $\mathrm{pH}$}

Figure 7 illustrates the effect pertaining to the $\mathrm{pH}$ of cobalt feed solution on the permeate water flux for FO flowing and FO batch processes. When the $\mathrm{pH}$ of feed solution decreases, water flux increased; after $4 \mathrm{hrs}$ it reached $21.09 \mathrm{l} /$ $\mathrm{m}^{2} . \mathrm{h}$ for the FO flowing process and $10.161 / \mathrm{m}^{2} . \mathrm{h}$ for the FO batch process at $\mathrm{pH} 2$. It is obvious

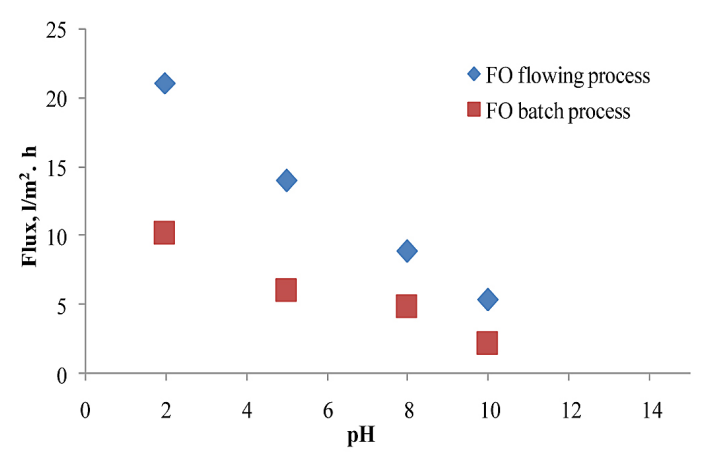

Figure 7. Water flux with different $\mathrm{pH}$ of feed solution for $\mathrm{FO}$ flowing and $\mathrm{FO}$ batch processes $\left(\mathrm{Co}^{+2}\right.$ ions concentration $=60 \mathrm{mg} / \mathrm{l}, \mathrm{KCl}$ concentration $=20 \mathrm{~g} / \mathrm{l}$, temperature of feed and draw solutions $=30^{\circ} \mathrm{C}$, time $=$ $4 \mathrm{hrs}$ ). For the FO flowing system (flow rate of feed and draw solutions $=50 \mathrm{l} / \mathrm{hr}$, and pressure $=0.25 \mathrm{bar}$ ). that lowering $\mathrm{pH}$ of cobalt feed solution increases the the dissolved salts solubility which leads to decreasing the rate of salt scaling on the CTA membrane surface and this caused lowering of the osmotic pressure as well as increased the permeate water flux. [Abid et al., 2012]. However, increasing the $\mathrm{pH}$ of cobalt feed solution would decrease the the permeate flux; after $4 \mathrm{hrs}$ it reached $5.34 \mathrm{l} / \mathrm{m}^{2}$.h for the FO flowing process and $2.14 \mathrm{l} / \mathrm{m}^{2}$.h for the FO batch process at $\mathrm{pH} 10$ due to the cobalt salt deposition on CTA membrane surface; this led to an external concentration polarization (ECP). This conclusion agrees with the previous investigation of [Nguyen et al., 2013].

\section{$\mathrm{Co}^{+2}$ ions Concentration in Permeate and Membrane Rejection Percentage (R\%)}

Figure $8 \mathrm{a}, \mathrm{b}$ shows $\mathrm{Co}^{+2}$ ions concentration in permeate increased and membrane rejection percentage decreased with the time for FO flowing and batch processes. The explanation for this behavior is that the increasing in metallic concentration decreases the rejection percentage, which reached $91.71 \%$ after $0.5 \mathrm{hr}$ and $81.19 \%$ after $4 \mathrm{hrs}$ for the FO flowing process and $87.71 \%$ after $0.5 \mathrm{hr}$ and $73.19 \%$ after $4 \mathrm{hrs}$ for the FO batch process, due to the formation of cobalt layer on the CTA membrane surface that retarded the back diffusion of the $\mathrm{Co}^{+2}$ ions from the CTA membrane surface to the bulk solution. Consequently, this caused a larger concentration prepared for its diffusion across the CTA membrane and this observation is compatible with previous results by [Achilli et al., 2010].
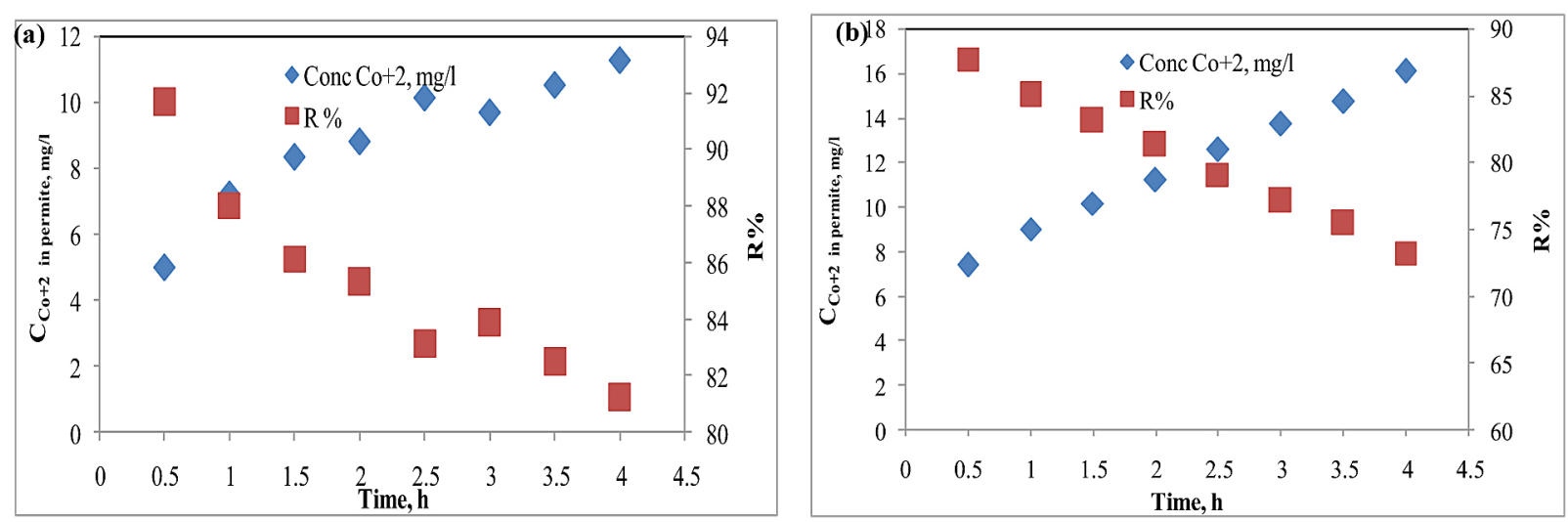

Figure 8. $\mathrm{Co}^{+2}$ ions concentration product and rejection percentage $(R \%)$ with the time for (a) the $\mathrm{FO}$ flowing process and (b) the FO Batch Process For both membrane module $\mathrm{Co}^{+2}$ ions concentration $=$ $60 \mathrm{mg} / \mathrm{l},\left(\mathrm{KCl}\right.$ concentration $=20 \mathrm{~g} / 1, \mathrm{pH}$ of feed $=5$, temperature of feed and draw solutions $\left.=30^{\circ} \mathrm{C}\right)$. For the FO flowing system (flow rate of feed and draw solutions $=50 \mathrm{l} / \mathrm{hr}$, and pressure $=0.25 \mathrm{bar}$ ). 


\section{Effect of FO batch and FO flowing processes}

Previous figures show the effect of the FO flowing and the FO batch processes on the water flux, the FO flowing process has a higher water flux than the FO batch process because the flow rate in hydration bag (batch process) was equal to $0 \mathrm{~m} / \mathrm{s}$. In the forward osmosis flowing system, the flow rate near membrane surface reduced the accumulated solute on both side of membrane (i.e reducing the external and internal concentration polarization) and led to an increase in the driving force $(\Delta \pi)$ and the water flux. Moreover, the effect of pressure that was applied on the feed side constituted another factor enhancing the water flux across the membrane.

\section{CONCLUSIONS}

From these results it is evident that for the FO flowing and the FO batch processes, the water flux increased by raising the concentration of draw solutions $(\mathrm{KCl})$ and temperature of both feed and draw solutions, and decreased by increasing the operating time of experiment, concentration and $\mathrm{pH}$ of feed solution. The rejection efficiency and water flux for the FO flowing process was higher than in the case of the FO batch process, so the FO flowing process had a higher efficiency than the FO batch process.

\section{Acknowledgements}

The author would like to thank the Mustansiriyah university (www.uomustansiriyah.edu.iq) Baghdad, Iraq for its support in the present work.

\section{REFERENCES}

1. Abbas S.H., Ismail I.M., Mostafa T.M., Sulaymon A. H. 2014. Biosorption of heavy metals: a review, Journal of Chemical Science and Technology, 3(4), 74-102.

2. Abdel-Raouf M., Abdul-Raheim A. 2017. Removal of heavy metals from industrial wastewater by biomass-based materials: a review, Journal of Pollution Effects \& Control, 5(1), 1-13.

3. Abid F.A., Zablouk M.A. Abid-Alameer A.M. 2012, Experimental study of dye removal from industrial wastewater by membrane technologies of reverse osmosis and nanofiltration, Iranian Journal of Environmental Health Science \& Engineering, 1-9.

4. Achilli A., Cath T.Y., Childress A.E. 2010. Selection of inorganic-based draw solutions for forward osmosis applications, Journal of Membrane Science 364(1-2), 233-241.
5. Ali H.M., Gadallah H., Ali S.S., Sabry R., Gadallah, A.G. 2016, Pilot-scale investigation of forward/ reverse osmosis hybrid system for seawater desalination using impaired water from steel industry, International Journal of Chemical Engineering, 1-9.

6. Changwoo K., Sangyoup L., Ho K.S., Menachem E., Seungkwan H. 2012. Adsorption boron transport in forward osmosis: measurements, mechanisms, and comparison with reverse osmosis, Journal of Membrane Science, 419-420, 42-48.

7. Cui Y., Ge Q., Liu X., Chung T. 2014. Novel forward osmosis process to effectively remove heavy metal ions. Journal of Membrane Science, 467, 188-194.

8. Gupta V.K., Pathania D., Sharma S. 2017. Adsorptive remediation of $\mathrm{Cu}$ (II) and $\mathrm{Ni}$ (II) by microwave assisted H3PO4 activated carbon, Arabian Journal of Chemistry, 10, S2836-S2844.

9. Hsiang T.C. 2011. Modeing and optimization of the forward osmosis process - parameters selection, flux prediction and process application, Ph.D, Thesis, National University of Singapore, Singapore.

10. Kamar F.H., Nechifor A.C., Nechifor G., Al-Musawi T,J., Mohammed A. H. 2017. Aqueous phase biosorption of $\mathrm{Pb}(\mathrm{II}), \mathrm{Cu}(\mathrm{II})$, and $\mathrm{Cd}(\mathrm{II})$ onto cabbage leaves powder, International Journal of Chemical Reactor Engineering, 15, 1-13.

11. Masoudzadeh M., Karachi, N. 2018, Removal of cadmium ion from wastewater using carboxylated nanoporous graphene (G-COOH), Eurasian Journal of Analytical Chemistry, 13 (4), 1-10.

12. Nematzadeh M., Samimi A., Shokrollahzadeh S., Behzadmehr A. 2015. Performance of potassium bicarbonate and calcium chloride draw solutions for desalination of saline water using forward osmosis, Trans. Phenom. Nano Micro Scales, 3(1), 29-36.

13. Nguyen C.N., Chen S.S., Nguyen T.H., Huang K. Z., LE Q. H. 2013. Exploration of ethylenediaminetetraacetic acid disodium (EDTA-2Na) salt as novel draw solution for forward osmosis process on dewatering of high nutrient sludge, Proceedings of the IETEC'13 Conference, Ho Chi Minh City, Vietnam, 1-7.

14. Patil O., Sayyad S.U. 2016. Forward osmosis application in treatment of wastewater, International Journal of Engineering Trends and Technology (IJETT), 37 (4), 233-239.

15. Qasim, M., 2013, Performance of forward osmosis using various membranes, M.Sc. Thesis, American University of Sharjah, United Arab Emirates.

16. Sharma S.K. 2015. Heavy metals in water: presence, removal and safety, Johnson Matthey Technol. Rev., 59 (4), 293-297.

17. Tang C.Y., She Q., Lay W.C.L., Wang R., Field R., Fane A. G. 2011. Modeling double-skinned FO membranes, Desalination, 283, 178-186. 